\title{
Regional Pride in Music Composition - Evoking Gamelan Sounds in Puteri Gunung Ledang
}

Marzelan Salleh Department of Music, Cultural Centre, University of Malaya marzelan@um.edu.my

(C) 2018 Cultural Centre, University of Malaya. This work is licensed under the terms of the Creative Commons Attribution (CC BY-NC-ND) (https://creativecommons.org/ licenses/by-nc-nd/4.0/)

Received 03 March, 2018; Accepted 13 December, 2018; Published 31 December, 2018.

\begin{abstract}
Regionalism is a demarcation of a definite area in terms of its topographical, economic, social relationships, government, and organisation. Inevitably, the concept of regionalism also extends into cultural and artistic phenomena, which includes music and music composition. By the 20th century up until now when global travel and communication is easy, does regionalism in music still exist? There is a misconception that regionalism is thought to have declined by globalisation when in fact, as a reaction, regional identity becomes stronger due to enhanced regional pride. In this article, I discuss the constructive and valuable importance of the emergence of regional pride in contemporary classical music compositions, and justify my approach through a composition for solo piano, Puteri Gunung Ledang, which includes active references towards gamelan musical nuances juxtaposed with Western compositional styles, thus demonstrating two contrasting regional musical influences colliding and collaborating into a single work of art, including an analysis of how my composition corresponds and supports the broader artistic phenomenon.
\end{abstract}

Keywords: music composition, contemporary music, solo piano, intercultural, regionalism, Malaysian composer

\section{Introduction}

\section{Music as a Universal Language? A New Take on an Old Question}

Music, which is a subjective form of art, is essentially an art of sound in time. Music's appeal lies in its emotional, nostalgic, and suggestive nature. Music's apparent depth of emotion and capacity to express things beyond the narrow limits of life reveals musical expression as a form of communication and understanding. We often perceive music as a universal language. But, is it really?

Like language, every culture has music. However, music and language systems vary from one culture to the other. Even though music preferences may be different between any two cultures, more often listeners show similar subjective and objective responses 
to the music. This has to do with the fact that some aspects of music are universal such as tempo, pitch, and timbre as well as the fact that it can communicate basic human feelings. For example, specific features of pitch or melody will contribute to the expression and emotion in music. For instance, the combination of high pitches, fluctuation in rhythm, and faster tempo convey happiness, while the opposite conveys sadness (van der Zwaag, Westerink \& van den Broek, 2011). So, we do not have to belong to or be born into a culture to be able to enjoy or understand music from that culture, which is to say we do not have to be Spanish to enjoy flamenco music or to be Asian to enjoy gamelan music.

In a language system, there are patterns of intonation and sound. We tend to forget that language also has melody and share similar elements with music such as pitch, rhythm, and tempo. Combination of these elements in language can convey emotion in speech, which appears to be universal across languages. For example, when listening to a piece of music, either from our culture or from another, listeners will work out emotions from melodic cues that imitate speech cues (Corrigall, 2013).

Language, by definition is a communication system consisting of meaningful words, with a set of rules combining those words into larger meaningful units. Like language, music has rules for ordering elements such as notes, chords, and intervals into more complex structures. It is these larger and more complex structures that convey emotional meaning. Therefore, music can be considered a universal system for communicating emotion. Music has the ability to express specific thoughts to anyone. Music making is a transcultural experience and activity, which has the power to evoke core feelings of a shared experience. And in that sense, music is a universal language.

\section{Regional Influences and Regional Identity in Music Composition}

According to Collins English Dictionary, regionalism is a powerful sense of belonging or allegiance that people have for their region of origin. (Collins English Dictionary, n.d.). It also includes the common interests of national groups, people, etc., living in the same part of the world. It also refers to a custom, accent, or other characteristics associated with a specific region, and certain regional quality or character. Regional qualities bring forth cultural identity. Therefore, to understand the nature of their music and to respect their specific qualities and cultural identity, the significant role of regionalism is highly regarded. However, it must be understood that a region may possess not just one, but many different cultural identities. Hence, exploratory efforts in music, especially in music compositions, are made to explore the contribution of music towards our sense of place as well as music's relationship towards a wider culture. Beyond this it is hoped that this type of exploratory music composition will encourage analytical discourse of regionalism in music composition in the world.

The present global situations of faster and easier travels and communications have put us all in a borderless world with limitless opportunities of rich cultural integration. Our present lives constantly intertwine around each other, yet these diversities have enriched our thoughts, arts, and lives. Music composition now offers an inventive musical freedom from the limitations of traditional methods and the potential to follow any idea wherever it may lead. Plenty of resources and tools for music composition from various cultures in the world has become integral in such intercultural activity 
until we have coined a term of intercultural music. The extensive idea of intercultural music has seeped into the ideas of many composers (Schwartz \& Childs, 1998). It is valuable to emphasise that this article will focus on the discussion and analysis of the implementation of the concept of interculturalism or the integration of different cultures into contemporary classical music. This article will not, therefore, venture into the discussion of other genres of music under the 'intercultural umbrella' such as world music, fusion music, folk music, etc. (Tenzer \& Roeder, 2011), which is of a different genre and as it would require a different discussion and analysis.

This article seeks to show the limitless possibilities and the rewards of making such an artistic effort of communicating through different cultures. It demonstrates the use of combining external and internal influences into a single work. Furthermore, in this article, I will discuss my approach of integrating 'gamelanistic' resources and referencing gamelan nuances with Western compositional styles and techniques. Before doing so, the following section will look into the various innovative and creative approaches of other notable contemporary classical composers in synthesising Eastern and Western musical and instrumental colours and gestures into their music compositions.

\section{Synthesis of Western and Asian Instrumental Colours and Gestures}

Until this present day, there have been attempts by composers to write for Asian traditional musical instruments. They have taken made attempts at writing for Asian instruments with a Western orchestra (Griffiths, 2010). I wish to highlight the compositional attempts of some distinguished contemporary classical composers coming from both Eastern and Western backgrounds and underline their contrasting approaches towards the synthesis of Western and Asian instrumental colours and gestures towards their compositions. These compositions include Toru Takemitsu's November Steps for biwa, shakuhachi and orchestra (1967), and Unsuk Chin's Su (Shu), concerto for sheng and orchestra (2009). In both compositions, worlds of different musical sounds collide and try to find their place in each other's musical space.

Toru Takemitsu (b. 1930), a Japanese composer, readily admits that that shakuhachi and biwa are two totally different sounding and characteristically different instruments from the orchestra, and blending them together was too big a void to overcome (Smaldone, 1989). Therefore, he eventually decided to make their differences the main theme of his November Steps (Burt, 2001). On the other hand, Unsuk Chin (b. 1961), a South Korean composer now residing in Berlin, has made the orchestra a shadow and echo of the sheng and at times also a contrasting entity to the sheng in her composition for sheng and orchestra entitled $\mathrm{Su}$ (Gothóni, 2018).

Before Toru Takemitsu and Unsuk Chin, the American composer Lou Harrison (b. 1917), was a reputable composer for his percussion music, his experiments in intonation, and his synthesis of East and West in his music (Schwartz \& Childs, 1998). The larger part of Lou Harrison's work lies in a wide variety of compositions for Western and Eastern instruments, notably for the gamelan, with which he experimented in later years such as Concerto for Piano and Javanese Gamelan (1987), Double Concerto for Violin and Cello with Javanese Gamelan (1982) and Main Bersama (for 
french horn and gamelan) (1978), which is just to name a few. In these three examples of his music, he incorporated musical elements of non-Western cultures written for Javanese gamelan instruments and Western instruments. Colin McPhee (b.1900) was a Canadian composer and his later music were highly influenced by Balinese musical culture and later on composed Tabuh-Tabuhan (for 2 pianos and orchestra) (1936) in the Balinese gamelan style.

As I stated in the beginning of this article, in response to the notion of music as a universal language, after looking into Takemitsu's and Unsuk Chin's music, I see that distinct regional elements and workings of music are actually able to operate together effectively in a single composition without necessarily overcoming each other. Instead, they are able to retain each distinct identity in a single composition. This personal point of view of mine was what brought me to initially explore this type of musical synthesis through my solo piano composition entitled Puteri Gunung Ledang.

As a Malaysian, I feel it is also appropriate to highlight fellow Malaysian composers pursuing similar compositional paths. Yet their works are not entirely alike in sound and compositional techniques. The compositions of Malaysian composers such as Mohd Yazid Zakaria, Ng Chong Lim, Teh Sze Siew, and Yii Kah Hoe are influenced by Malaysian traditional music (Lie, 2013). Mohd Yazid's compositions for the orchestra namely, Mahsuri, Heritage, and Angin are examples of the embodiment of the various aspects of Malay traditional art forms and his major musical concept almost always features Malaysian traditional dance rhythms. Evoking a tranquil wide-open padi field, Mahsuri sees the oboe depicting a serunai and the use of bonang with the brass section bringing out the Malaysian flavour. The joget dance rhythms are highlighted in Heritage through the use of framed drums imitating the traditional rhythms of the kompang and kendang; Angin's heavily induced ostinato is almost trance-like resembling the metaphysical elements in Kelantanese traditional performances.

Ng Chong Lim's works for orchestra, Rimba and Xiang, demonstrate his affinity with Chinese philosophy and aesthetics. The quiet and tranquil Rimba and Xiang is an exemplification of Buddhism's philosophy of simplicity. Ad libitum passages in both works calls for orchestra players to play freely within a time frame with notes specifically chosen by the composer. This has to do with Buddhism's concept of 'living in the moment'. The three basic principles of Buddhism, which are impermanence, simplicity, and moderation, have greatly influential to $\mathrm{Ng}$ 's musical aesthetics and concepts.

Teh Sze Siew's Bamboo Forest and Temple of Heaven are filled with Chinese inflections. There is an endless influence of Chinese culture in her music with her soft, oriental personality reflected through the textures, rhythm, harmonies, and melodies of her music.

Yii Kah Hoe's works are very well received in South-East Asia and beyond. His compositions place a lot of importance into tone colours, performance techniques, and ethnic elements. Bayang and Wayang Kulit showcases his fascination for traditional theatre genres and ritual ceremonies found in multi-ethnic Malaysian culture. Another composition, Gongan, for prepared piano and oboe sees the prepared piano producing 
sounds similar to the metallic sounds of the canang and kesi of the traditional theatre of wayang kulit.

Subsequently, my composition for solo piano, Puteri Gunung Ledang is creating a connection by having both worlds of instruments correspond with each other in their own ways, not by having them make a certain similar connection, but instead, through the realisation that traditional musical qualities cannot be changed, and neither can western musical qualities. Therefore, the only way to achieve a unified sound and structure of both worlds is to merge and fix them together through their differences and dissimilarities.

Instead of integrating Asian traditional instruments into an orchestra, Puteri Gunung Ledang is a composition for piano, a Western musical instrument, using only gamelaninduced sounds for its musical nuances. Therefore, the decision to compose Puteri Gunung Ledang, for solo piano, aims towards using only conventional musical notation to deliver a composition of entirely gamelan-sounding themes and motives. In this article, I will therefore demonstrate and analyse the possibilities in writing a gamelan-sounding piano work.

\section{Composition Technique and Style of Puteri Gunung Ledang}

The composition technique and style of Puteri Gunung Ledang shows a certain degree of a hybrid of gamelan music and Western tradition of piano music. My creations more or less always come from my own personal experiences and my imagination always comes out from these experiences in life. After living in the United Kingdom for seven years after growing up in Malaysia for more than twenty-five years, all these experiences crossing together come out of my music. My early musical experiences were in Western traditional classical music, and only later on was I exposed to Malaysian traditional music. All my earlier and later experiences have somehow merge as they come out in my music today. Now, as a composer, I feel myself most closely defined as a contemporary classical composer.

\section{Composing Puteri Gunung Ledang, for solo piano}

\section{Gamelan Nuances - Pitch and Thematic Material}

Gamelan is the traditional ensemble music of Java and Bali in Indonesia, made up predominantly of percussive instruments. Gamelan is still commonly played on formal occasions and in many traditional ceremonies. Gamelan music is present in Malaysia and Indonesia and remains an integral part of both cultures. The Malay gamelan, which exists today in Malaysia, is basically from the courts of Riau-Lingga, Pahang and Terengganu. Although originated from the land of Java, Indonesia, the Malay gamelan has developed a distinct identity compared to the Javanese and Balinese gamelan from Indonesia. The basic gamelan consists of eight different instruments, which are Gong Agong, Gong Sawokan, Gendang Ibu, Gendang Anak, Saron Pekin, Saron Baron, Gambang, and Kenong. Each of these instruments has a specific role in the music of gamelan (Matusky \& Tan, 2017). For example, saron baron plays the main melody while saron pekin and gambang duplicate and accompany the main melody with ornamentation. The two gongs and kenong act as time markers and both gendangs play specific rhythmic patterns. Two most widely known types of gamelan 
music exist in Indonesia, which are the Balinese gamelan and the Javanese gamelan (Lindsay, 1992; Tenzer, 2013). Malaysian gamelan is same in character as Javanese gamelan music, which is calmer, sensuous, and soft in character and played at a lower speed, while Balinese gamelan music is more active, bright, aggressive and fast (Malm, 1996). I have used modes drawn from Indonesian traditions and Malaysian gamelan, which resembles Javanese gamelan for this composition.

I have selected two modes from the gamelan music to portray a Javanese princess as the main character of this piece. Puteri Gunung Ledang, or Princess of Mount Ledang, is a legendary Javanese princess from Indonesia. Her love for Hang Tuah, a Malay warrior, is sacrificed for the sake of his life, which was in the hands of the Malaccan Sultan, who was also vying for her love. The position of the princess in this love triangle sets the backdrop for this solo piano piece.

The pitches that I have used for Puteri Gunung Ledang are not specifically related to any form of the gamelan modal systems but portray a subtle reference to that practice. The two modes used are slendro and pelog. Slendro and pelog scales are often used in gamelan music of Southeast Asia such as in Indonesia and Malaysia. Slendro is often used in Malaysian gamelan music while pelog is often found in Indonesian gamelan music. Appropriately for this piece, the pelog scale represents the princess and the slendro scale represents Hang Tuah.

For Puteri Gunung Ledang, I have chosen gamelan music to be highlighted, which suits the background of this composition most appropriately as it is in line with the identity of the piece, which is representing a legendary Javanese princess, and her love and sacrifice for her lover Hang Tuah. The slendro (Figure 1a) and pelog (Figure 1b) modes in Puteri Gunung Ledang are notated out below.

\section{a. Slendro}

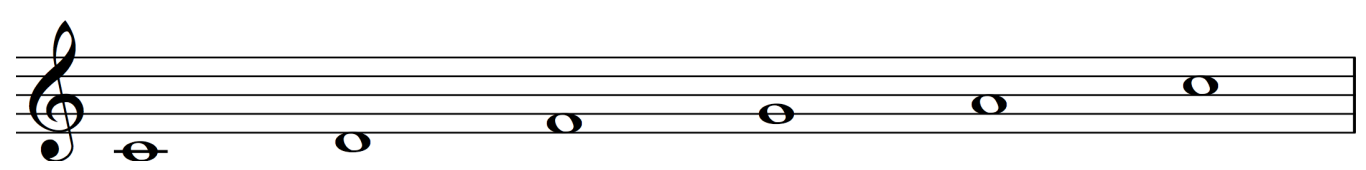

\section{b. Pelog}

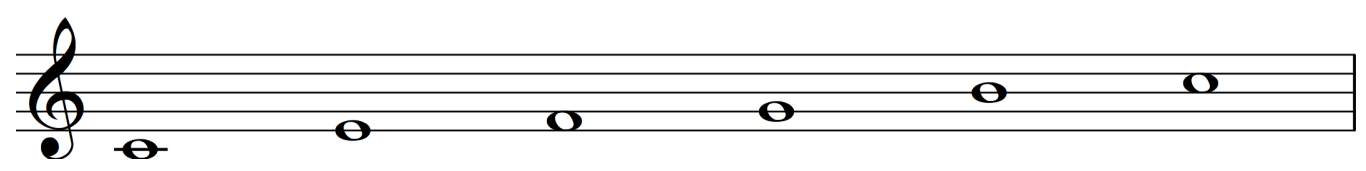

Figure 1. 'Puteri Gunung Ledang' (2015) for solo piano by Marzelan Salleh showing a.Slendro and b. Pelog. 


\section{Gamelan Nuances - Harmonic Colours and Textures}

I have used these two modes separately and at times together in juxtaposition or followed by one another in a dovetailing manner thus creating harmonies or heterophony texture within this piece (Figure 2). And at times, more often than not, I begin the slendro and pelog scales from different degrees, meaning not only starting from the beginning of the slendro or pelog scale but from different notes in the scales. This directly gives an audibly different sense of colour instantly.
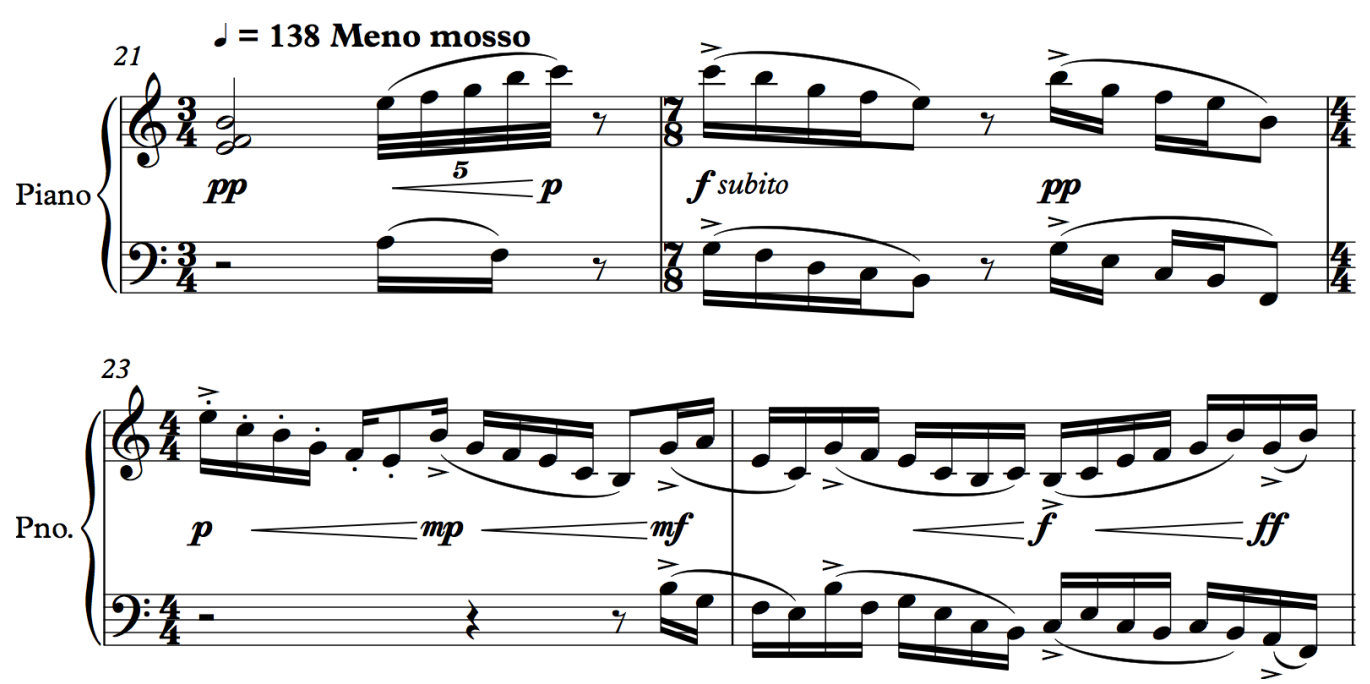

Figure 2. 'Puteri Gunung Ledang'(2015) for solo piano by Marzelan Salleh showing Gamelan nuances for Slendro and Pelog

At bars $40-45$, quintuplets and semiquaver triplets run through a flurry of gamelanlike scales, accompanied in the bass clef by lower sounding punctuation notes similar to the sounds of a kenong in a Gamelan ensemble. These kenong accompaniments act as a counter-melody to the melody above (Figure 3). Kenongs are gong-like instruments, similar to a bonang but bigger. We play them by hitting a soft mallet on their knobs. They are wide and tall, cradled gongs, placed on their side suspended on cords on a rack. In traditional gamelan music, kenongs are punctuating instruments, linking the gongs to the rest of the gamelan ensemble. 

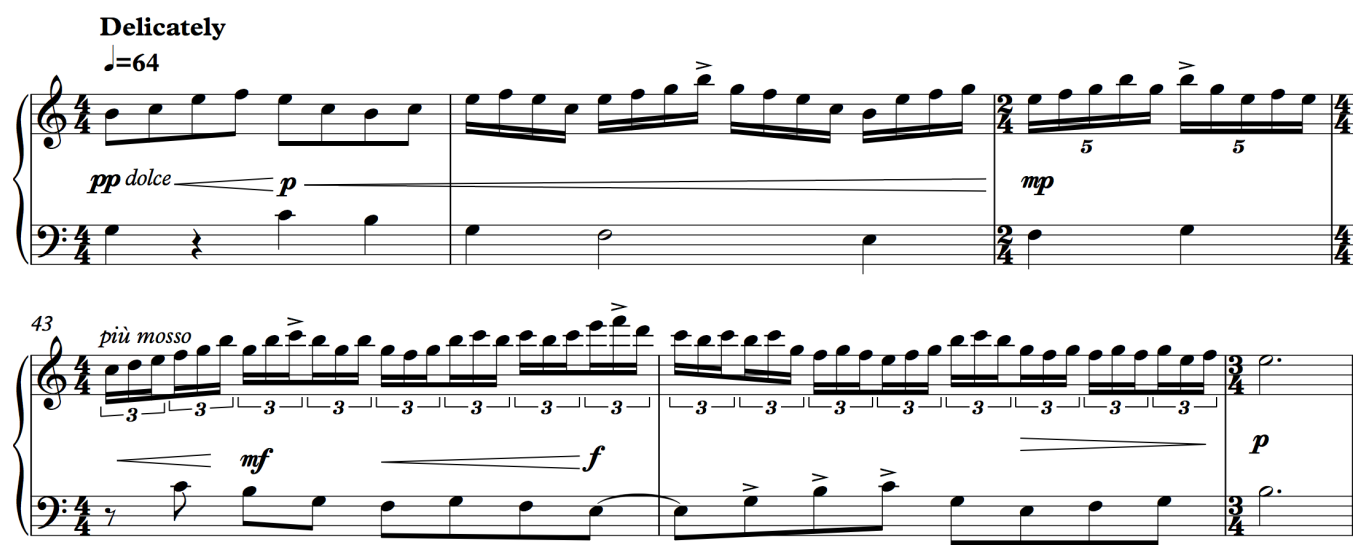

Figure 3. Gamelan-like scales accompanied by kenong counter-melody

As shown in Figure 1a and Figure 1b, both gamelan scales in Puteri Gunung Ledang are in the white keys without any chromatic inflections or passing notes. Therefore, one might expect to hear in this piece an open sound of non-tension. But to counter and create tension here in this music, I have inserted minor second intervals and tritone intervals from the gamelan scales, thus naturally adding colouristic qualities to the music (Figure 4). These notes, which I refer to as 'interferences', are added to the aesthetic of the music. They are merely intuitive inflections and are not related to any chromaticism or tonality relations.

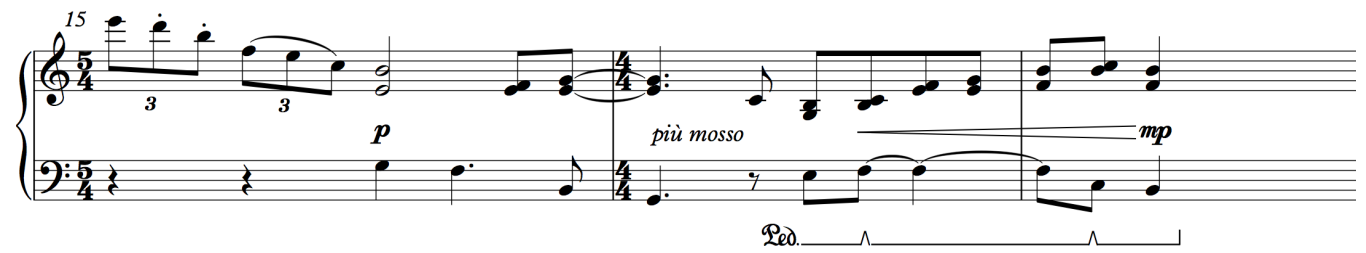

Figure 4. Minor second and tritone intervals

Even in the harmonies, vertical additions of these minor seconds and tritones are present to deliver darker colours in the music (Figure 5).

.$=48$ A tempo

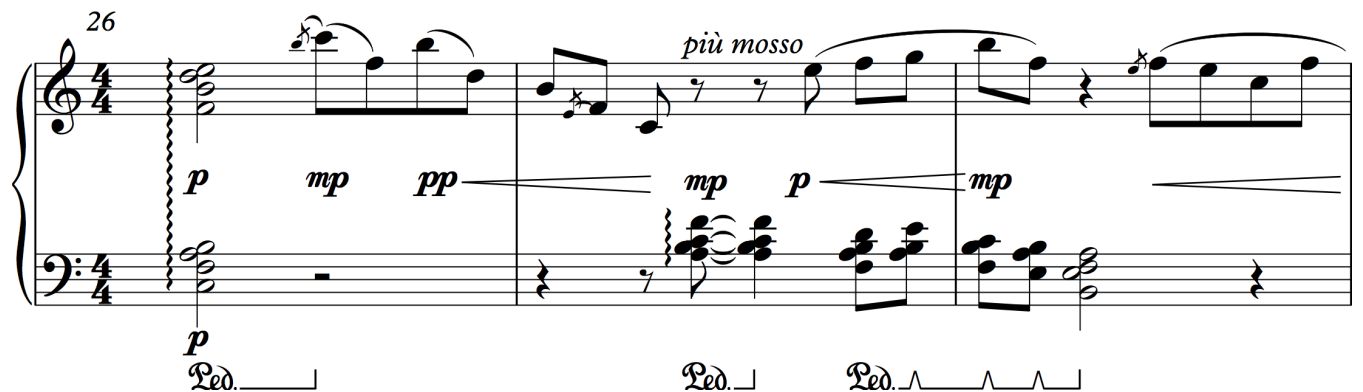

Figure 5. Minor second and tritone intervals in the harmonies 
In order to create a constant sense of movement and direction in this piece, there is an audible sense of the pitches slowly evolving. Highlighting these colourful evolving pitches involves careful compositional techniques, which refers to considerations of tone colour, transposition, register, doublings and dynamics. The two distinctive representations of characters in the piece using two different modes are dramatised more effectively when I implement them into different registers and transpose them throughout the piano. Ultimately, in the end, these pitches will provide the overall form and structure of the pitch material.

Puteri Gunung Ledang in shape has a more continuous arc and broader gestures. Having made Puteri Gunung Ledang a fully notated piece makes it even easier to have a greater degree of pitch control. The use of octave and unison doubling between different groups are used to highlight a particular pitch or group of pitches. As an end result, the pitches of Puteri Gunung Ledang are connected audibly in the overall structure. This piece has shown how strands of unity can be maintained in this music, as recurrent focal pitch classes and pitch-class groupings form large-scale associations within a modal framework.

\section{Form and Structure}

Besides writing normal musical lines in the score, there are specific lines defining certain parts of the music and certain rhythmic patterns, which are always imitated or mixed up in the score. The most important thing to me when composing a piece of music is the power of structure. To achieve a powerful structure, I treat the whole piece as one. For example, in Puteri Gunung Ledang, I have written it as one thematic relationship. And to strengthen my thematic material, I have opted for the slendro and pelog scales to distinguish and establish the identity of the Javanese princess and her relationship issues. Therefore, a strong establishment of theme and structure will inevitably determine the shape and form of this piece. Puteri Gunung Ledang's seamless flow of music and drama is directional for the audience without any abrupt interruptions, but only for dramatic purposes.

\section{Conclusion}

Composers have incorporated foreign and folk elements into their music for centuries, but never as extensively or with the same attitude as in recent music. I believe the role of a composer is to continuously develop the knowledge of music and composition. As a composer, I view artistic disciplines and music especially as organic in nature, meaning they are ever-changing and evolving. In my opinion, regionalistic influences in music are simply opening up new doors and new turns in music composition and further enriching the musical sound and experiences of its audiences and actually are not meaning to change any culture or tradition. Therefore, the ways of representing or strengthening my own (regional) identity in my music, I realise, is quite different now in current times, which was why I was particular determined to compose Puteri Gunung Ledang.

Puteri Gunung Ledang is an example of the use of a wider regionalism in its composition. It is a product of two main regional influences of Europe and Asia, including influences within Asia, which are Malaysia and Indonesia. As a result, Puteri 
Gunung Ledang shows the potential and value of regional identity towards strengthening regional pride. Although through combining two contrasting regional musical influences, the collaboration between them has developed into producing a work of art, which is clear in its source and identity. In its own compositional way, Puteri Gunung Ledang has strengthened regional pride of Asia (Malaysia and Indonesia) through the usage of Gamelan scales but with Western compositional techniques, musical form and structure, as well as musical instruments.

Through the progress of globalisation and the search of a universal language or a universal system for communicating emotion, music has developed into various terminologies. New compositions defined as multi-cultural, cross-cultural, or intercultural, are deriving influences from two or more different regions. What is the difference between multicultural, cross-cultural, and intercultural? While they all might be under the same umbrella, they describe entirely different notions. The differences in the meanings have to do with the perspectives we take when interacting with influences from other cultures including how deep the relationship, the amount of exchange, and transformation occurring in the processes. In my point of view, composers and musicians must be multi-lingual in music too. This means adopting a holistic point of view that moves beyond Eastern and Western cultures. This does not mean that regional divisions are destined to disappear entirely, but only that they will become less prominent. Although with diminishing boundary lines, regionalism persists not only through survival but also actually through the strengthening of regional pride especially for a composer when each element deriving from different sources are put in a parallel situation contesting for valuable identity.

\section{References}

Burt, P. (2001). The Music of Tōru Takemitsu. New York: Cambridge University Press.

Corrigall, K. (2013). Music: The language of emotion. In C. Mohiyeddini, M. Eysenck, \& S. Bauer (Eds), Handbook of psychology of emotions: Recent theoretical perspectives and novel empirical finding (Vol.2, pp. 300-305), Hauppauge, NY: Nova Science Publishers.

Gothóni, M. (2018). Chin, Unsuk. Su. Retrieved from https:/www.boosey.com/cr/ music/Unsuk-Chin-Su/52419.

Griffiths, P. (2010). Modern Music and After (3rd ed.). Oxford: Oxford University Press.

Lie, L. P. H. (2013). Music of the Malaysian Philharmonic Orchestra (MPO) Forum 2 Finalists: Reflections on Malaysian Multiculturalism. Wacana Seni Journal of Arts Discourse, 12.

Lindsay, J. (1992). Javanese gamelan: traditional orchestra of Indonesia. Oxford University Press. 
Malm, W.P. (1996). Music Cultures of the Pacific, the Near East, and Asia. Upper Saddle River, New Jersey: Prentice Hall Inc.

Matusky, P. \& Tan, S. B. (2017). The Music of Malaysia: The Classical, Folk and Syncretic Traditions. Abingdon: Routledge.

Regionalism. (n.d.). Collins English Dictionary. Retrieved from https:// www.collinsdictionary.com/dictionary/english

Smaldone, E. (1989). Japanese and Western Confluences in Large-Scale Pitch Organization of Tōru Takemitsu's November Steps and Autumn. Perspectives of New Music, 27(2), 216-231. http://doi.org/10.2307/833413.

Schwartz, E. \& Childs, B. (Eds.). (1998). Contemporary Composers on Contemporary Music. New York: Da Capo Press.

Tenzer, M., \& Roeder, J. (2011). Analytical and Cross-Cultural Studies in World Music. Oxford: Oxford University Press.

Tenzer, M., \& Moja, I. M. (2013). Balinese Gamelan Music: (Downloadable Audio Included). Clarendon: Tuttle Publishing.

van der Zwaag, M. D., Westerink, J. H., \& van den Broek, E. L. (2011). Emotional and psychophysiological responses to tempo, mode, and percussiveness. Musicae Scientiae, 15(2), 250-269. 